\title{
REFLECTIONS ON THE INSERTION OF THE NUTRITION DISCIPLINE IN NURSING EDUCATION
}

\author{
Cátia Feresin ${ }^{1}$ \\ Maria Cecília Sonzogno²
}

Feresin C, Sonzogno MC. Reflections on the insertion of the nutrition discipline in nursing education. Rev Latinoam Enfermagem 2007 novembro-dezembro; 15(6):1092-8.

This study aimed to characterize the Nutrition discipline in six undergraduate courses in nursing regarding to the professor background, workload, content, strategies of education and evaluation from the perspective of the professor who teaches it. This is a descriptive research, carried out through semi-structured interviews, analyzed through the Thematic Analysis. It was verified that the discipline content approaches Nutrition in the vital cycle in the prevention of illnesses, as well as, in the healing aspect. The importance of the professor to be attentive to the content complexity necessary to the Nursing Education is highlighted. Nutrition knowledge favors the performance of the Nurse in a multifunctional health team. The formation of study groups with professors from Nutrition disciplines in the health area of undergraduate programs is suggested.

DESCRIPTORS: education, nursing; education, higher

\section{REFLEXIONES SOBRE LA INSERCIÓN DE LA DISCIPLINA DE NUTRICIÓN A LA FORMACIÓN DEL ENFERMERO}

El objetivo de este estudio fue caracterizar la disciplina de Nutrición en seis cursos de la graduación en cuanto a la formación docente, carga horaria, contenidos, estrategias y evaluación a partir de la óptica del profesor que la ministra. Trátase de una investigación descriptiva, realizada a través de entrevistas semiestructuradas, analizadas por medio del Análisis de Contenido Temático. Se pudo observar que el contenido de las disciplinas abarca tanto el aspecto de la Nutrición en el ciclo vital como la prevención de la enfermedad en cuanto al aspecto curativo. La importancia del profesor estar atento a la complejidad de los contenidos necesarios para la formación del enfermero fue enfatizada. Los conocimientos de la Nutrición favorecen la actuación del enfermero en el equipo multiprofesional en salud. La evaluación del aprendizaje de los alumnos es predominantemente somativa, dificultando la posibilidad de retomar sus errores. Sugiérese la formación de grupos de estudio de profesores de las disciplinas de Nutrición en Cursos del área de la salud.

DESCRIPTORES: educación en enfermería; enseñanza superior

\section{REFLEXÕESSOBRE A INSERÇÃO DA DISCIPLINA DE NUTRIÇÃO NA FORMAÇÃO DO ENFERMEIRO}

Este estudo visa caracterizar a disciplina de Nutrição ministrada em seis cursos de graduação em enfermagem quanto à formação do docente, carga horária, conteúdos, estratégias de ensino e avaliação a partir da ótica do professor que a ministra. Trata-se de uma pesquisa descritiva, realizada por entrevistas semi-estruturadas, analisadas por meio da Análise Temática. Verifica-se que o conteúdo das disciplinas abrange tanto o aspecto da Nutrição no ciclo vital e na prevenção de doenças quanto no aspecto curativo. Salienta-se a importância do professor estar atento quanto à complexidade dos conteúdos necessários para a formação do enfermeiro. Os conhecimentos da Nutrição favorecem a atuação do enfermeiro na equipe multiprofissional em saúde. Sugere-se formação de grupos de estudo de professores das disciplinas de Nutrição em Cursos da área da saúde.

DESCRITORES: educação em enfermagem; ensino superior

${ }^{1}$ MS in Sciences, Professor at Santa Marcelina Facult, Brazil, Professor at the Uni-FMU Universitary Center, Brazil, e-mail: catiant@bol.com.br; ${ }^{2}$ Professor, São Paulo Federal University, Paulista Medical School, Brazil, e-mail: mcsonzogno@uol.com.br 


\section{INTRODUCTION}

This article summarizes some of the results obtained in the Master's Thesis presented at the Program "Health Science Teaching", offered by the Center for the Development of Superior Health Education at the Federal University of São Paulo / Sao Paulo College of Medicine.

There are many challenges involved in the activity of teaching Nutrition in Nursing Undergraduate Courses, such as encouraging students to think critically, through discussion on relevant themes regarding the body of nursing knowledge. Nurses should acquire knowledge in Nutrition because they use this knowledge in several practical settings, in health promotion as well as in the curative aspect. Considering that Nutrition is elementary for life maintenance, and that nurses are health professionals with certain responsibilities regarding the patient's overall healthcare, it becomes clear that knowledge in Nutrition is fundamental.

The nurse, a member of the health team, should try to help preventing malnutrition. They should assist nutritionists and physicians in the early identification of physical signs of malnutrition, for instance, by providing information regarding the patient's acceptance of meals. They should also help in malnutrition treatment, overseeing and transmitting important information to the nursing team regarding the importance of nutrition in the recovery of malnourished patients. Finally, as members of the health team, nurses should cooperate with patient nutrition $^{(1)}$.

The faculty member responsible for the Nutrition subject in a Nursing Undergraduate Course should pay close attention to the areas nurses work in, as well as their responsibilities, to be able to verify in which moments their professional practice and knowledge in nutrition would be useful. The Nutrition subject should cover all of these aspects.

There is a need for studies with a view to improving Nutrition teaching, so students can acquire the necessary competence for their further professional practice. They should be able to conciliate techniques with a critical view, and apply that knowledge into their practice setting ${ }^{(2)}$.

For some time, nursing undergraduate course curricula included nutrition classes. However, as of the implementation of the 1994 Minimum Curriculum, nutrition was no longer included ${ }^{(1)}$.
In 1996, the publication of the Law of Educational Foundations and Guidelines, Law 9394 of December 20 1996, gave higher education institutions the independence to outline their own curricula. It also allowed greater autonomy to elaborate the Pedagogical-Political Project, from a perspective of collective construction, interdisciplinarity and integration. Minimum curricula were then extinct ${ }^{(3)}$.

The Brazilian Ministry of Education and Culture gathered education institutions and professionalizing associations to discuss curricular guidelines for higher education courses. Shortly before this event, as of 1994, the Brazilian Nursing Association had already begun to hold National Seminars on Nursing Education in Brazil in order to discuss nursing education.

The National Curricular Guidelines for nursing courses were created in 2001, through Resolution Number 3 by the National Education Council on 7 November $2001^{(4)}$.

Some excerpts of the National Curricular Guidelines (NCG) for nursing undergraduate courses state the pertinence of nutrition in nursing education.

NCG's article 4 refers to nurses' general skills and abilities. Section III addresses communication with other healthcare professionals, including nutritionists. It becomes clear that it is important for nursing undergraduates to get contact with teachers from diverse areas, so the student begins to contact other health professionals. Article 5 addresses specific skills and abilities, and section VII states "working in integral health care programs for children, adolescents, women, and the elderly". In this section, it becomes evident that nutrition contents are pertinent in the life cycle in order to make nursing care more effective ${ }^{(4)}$.

Section XXXII states: "taking care of one's own physical health ...". This also shows the relevance of knowledge regarding a balanced diet, for nurses as well, because nutrition allows for the context of subjects being important in both the personal and professional domains ${ }^{(4)}$.

Article 6 addresses the essential contents for the nursing course. The nutrition subject permeates Health and Biological Sciences, including Nursing, considering that this scientific content provides support to work with Nursing Care ${ }^{(4)}$.

Currently, the Higher Education Evaluation System proposed by the Brazilian Ministry of Education and Culture (MEC), called the National Higher Education Evaluation System, consists of the National Student Performance Exam. The latter was administered in 
Nursing in 2004, and contains questions that involve nutrition in the curative and hospital environment, as well as in health promotion. These questions associate child growth with eating ${ }^{(5)}$.

This type of evaluation reinforces the need for nurses to have basic knowledge regarding nutrition in the life cycle as well as nutrition in the face of diseases.

From this perspective, the purpose of this study is to characterize the Nutrition subject taught in nursing undergraduate courses regarding teachers' education, class hours, contents, teaching and evaluation techniques from the perspective of the responsible faculty.

\section{METHODOLOGY}

This is a descriptive study, defined as "studies characterized by the need to explore an unknown situation, which requires more information"(6).

The target population in this study was comprised of six faculty who taught nutrition in nursing undergraduate courses in six higher education institutions in the city of São Paulo. In order to better identify the study collaborators' profile, their information was compiled in Table 1.

Table 1 - Identification of the faculty who participated in the research. São Paulo, 2005

\begin{tabular}{ccclll}
\hline Faculty & $\begin{array}{c}\text { Undergraduate Graduation } \\
\text { course }\end{array}$ & year & $\begin{array}{l}\text { Graduate } \\
\text { course }\end{array}$ & $\begin{array}{c}\text { Time of } \\
\text { experience in } \\
\text { with nutrition } \\
\text { subject }\end{array}$ & Type of \\
institution
\end{tabular}

Based on the discussion about the concepts regarding the nutrition subject in nursing undergraduate courses, data were collected through semi-structured interviews.

The interviews were recorded, transcribed and then analyzed by Thematic Analysis or Categorical Analysis, in which the categories were obtained by reading the contents. The texts were dismembered into units, cross-sectionally, and these selected categories were later analyzed. The research categories were not chosen a priori; rather, they emerged from the incessant readings, and were established throughout the research ${ }^{(6-7)}$.

After receiving authorization from the involved Ethics Committee, the lead researcher conducted the interviews at higher education institutions, guaranteeing research subjects' anonymity by administering the Informed Consent Term.

\section{RESULTS AND DISCUSSION}

Inserting the Nutrition subject in Nursing Undergraduate Courses

Table 2 - Nutrition class hours and the moment it occurs in the researched nursing undergraduate courses. São Paulo, 2005

\begin{tabular}{|c|c|c|c|c|}
\hline Institution (I) & Subject & Class Hour & Course Perioc & Theory/practice \\
\hline 11 & $\begin{array}{l}\text { Nutrition and } \\
\text { Dietetics }\end{array}$ & $36 \mathrm{~h}$ & 6th Semester & Theoretical \\
\hline 12 & $\begin{array}{l}\text { Nutrition and } \\
\text { Dietetics }\end{array}$ & $\begin{array}{l}30 \mathrm{~h} \\
30 \mathrm{~h}\end{array}$ & $\begin{array}{l}\text { 1st Semester } \\
\text { 2nd Semester }\end{array}$ & Theoretical \\
\hline 13 & $\begin{array}{l}\text { Nutritional } \\
\text { Aspects of the } \\
\text { Health-Disease } \\
\text { Process }\end{array}$ & $75 \mathrm{~h}$ & 3rd Semester & Theoretical \\
\hline H & $\begin{array}{l}\text { Nutrition Applied } \\
\text { to Nursing }\end{array}$ & $40 \mathrm{~h}$ & 3rd Semester & Theoretical \\
\hline 15 & $\begin{array}{l}\text { Diet Therapy I and } \\
\text { Diet Therapy II }\end{array}$ & $\begin{array}{l}40 \mathrm{~h} \\
40 \mathrm{~h}\end{array}$ & $\begin{array}{l}\text { 3rd Semester } \\
\text { 4th Semester }\end{array}$ & Theoretical \\
\hline 16 & Nutrition & $\begin{array}{l}32 \mathrm{~h} \\
32 \mathrm{~h}\end{array}$ & $\begin{array}{l}\text { 2nd Year } \\
\text { 3rd Year }\end{array}$ & $\begin{array}{l}\text { Theoretical and } \\
\text { practical }\end{array}$ \\
\hline
\end{tabular}

Table 2 shows the large variation regarding class hours and it is observed that this class is strictly theoretical. In addition to the contents about Science and Nutrition, there is a need to insert contents about Science and Nutrition in classes on other subjects, with a view to providing integration.

Contents

Regarding the main contents the faculty addressed in class, apparently, there was great diversity, but all contents were associated with basic nutrition concepts, nutrition in the life cycle and in diseases. The following selected reports show the contents addressed in class.

We address the basic part, we also add the Normal Eating part regarding women who are pregnant or breastfeeding, and Diet Therapy (P3).

Nurses use nutrition knowledge to know the feeding characteristics with a view to health 
maintenance, as well as for the curative aspect. The logic of first addressing nutrition in disease prevention and later nutrition in ill patient recovery is pertinent, because emphasis on disease prevention is important. When selecting the contents for a course, it should be very clear what its use will be and what the professionals' work areas are and, therefore, where the professional will use those concepts.

Regarding the National Curricular Guidelines for nursing undergraduate courses, when the contents refer to nutrition in a preventive and curative sense, they address the general and specific competencies regarding the aspect of nutrition knowledge acquisition. However, to use this knowledge in their professional practice, students must develop additional competencies; for instance, the ability to work in a multiprofessional team ${ }^{(4)}$.

Some diseases are closely associated with nutrition and, among health care professionals, the nutritionist is the main professional involved in nutritional patient care. Nonetheless, it is clear that collaborative work with nurses is important, with a view to making efforts to better meet the patients' nutritional needs.

Undergraduate course curricula in nursing, as well as in any other health area, recommend contents about the nutritional status of the Brazilian population ${ }^{(8)}$.

Planning a course or class is extremely important. One of the criteria to choose contents is to analyze content sequence and contextualization, so students can understand how to use it $^{(9)}$.

Teachers should know how to select what is important for nurses, regarding nutrition contents, and not simply address the complex contents for the simple reason that they have studied much more and are specialized in a certain subject. These are some of the statements from two faculty:

... I talk about hospital diets, so they recognize them: I only talk about physiopathology and what should be restricted. I do not talk about figures, for example, saturated fatty acids must represent $7 \%$ of total fat, because they will not use that (P1).

It is important to emphasize that the above mentioned contents stated by the faculty are covered in the general and specific competencies and abilities present in the National Curricular Guidelines of the nursing undergraduate course, regarding Article 5, referring to nurses' participation in integral health care programs for women, children, adults and elderly. Contents regarding nutrition in the life cycle cover the guideline recommendations ${ }^{(4)}$. ...we must know this, because nurses see patients more frequently and you have to check on them, you have to tell the nutritionist about a patient who is not eating... (P5)

This statement reflects the work of the multiprofessional team, in which two professionals, the nutritionist and the nurse, work with the common objective of recovering or maintaining the patient's nutritional state.

Teaching Strategies

The teachers' statements regarding the teaching strategies show their involvement with their students' teaching-learning process, since they mention their concern with technique diversification.

One teacher said:

... the students usually present good seminars because they occur throughout the year, so I stop for about twenty minutes and, in each class, one or two seminars are presented ... (P2)

It is rather pertinent that students plan and prepare their seminar because, while they research on the subject, they acquire autonomy for knowledge construction. Nowadays, it does not take long for any knowledge to become obsolete. Hence, there should be graduate teaching strategies to encourage a permanent search for knowledge.

Another relevant aspect in these statements is that teachers report cases studies as an appropriate strategy to teach nutrition and nursing:

I use the case study of a pregnant woman, .... and I want the student to evaluate ... the weight ... the food .... so that is how I work (P3).

Teachers use the self-evaluation of one's eating habits to present the recommendations for a balanced diet in the Brazilian population, with a view to disease prevention and health maintenance. By evaluating their own eating habit, the students are able to pay closer attention and assign more meaning to the patients' eating habits.

Observe what they say about this strategy:

... I work with an evaluation of the students' own eating habits, and then we do an evaluation; and then, based on those results, we work, or else it would be too theoretical and hard to deal with (P3).

It is important to say that the above reports are in agreement with the Nursing Undergraduate Course (NCG), regarding Section XXXII referring to nurses' self-care. The analysis of what students achieve through the referred strategy is effective because it provides students with feedback about their own health regarding eating habits ${ }^{(4)}$. 
Teaching strategies require teachers to reflect about what to choose: "When students learn specific contents, they also learn a certain way to think about it, to elaborate it; therefore, each area demands specific ways of teaching and learning, which explicit the respective rationale ${ }^{\prime(10)}$.

Learning evaluation

It is observed that the evaluation is based on verification. It is basically comprised of theoretical evidence, with multiple-choice tests.

Teachers seldom mention the possibility of the evaluation to surpass the written exam, and state that the evaluation consists of:

It is a test, or multiple-choice test, or a yes-or-no test, and students only fail if they really did not study, so it is a cutoff point ( $P 1)$.

Evaluations are still in that old-fashioned method, tests .... you really see this evaluation as a document (P4).

Learning evaluation is considered a complex field; it is important for teachers to have a clear definition about what they desire students to learn, then decide on which evaluation instruments will be part of the learning process. The data obtained from the teachers' statements permit affirming that, at these institutions, evaluation still takes place only to verify information retention; there is no evaluation of the learning process as a whole.

In a diverse way, another teacher elaborated the written exam and was able to incorporate the student's analysis, through practical cases:

... when we have a small class, you can easily see the student's development, a larger class is more difficult, but there is no other way except for exams and assignments, right? ... and in exams I usually include cases ... so they can think, so they can see what actually happens (P4).

It is observed that teachers do not have many alternatives to plan the written exam, when they teach large groups but, still, they should search, creatively, to assign meaning to learning. Even on an exam, the teacher can use questions that contextualize professional practice. For instance, questions in the $\mathrm{NCG}^{(5)}$.

One teacher stated the concern about discussing the evaluation with students, to provide feedback about their goals achievement, and which aspects should be reviewed in order to improve. This teacher shows concern with the student's learning: when produced, new knowledge surpasses previous knowledge, which was new and became old, and is 'available' to be surpassed by other knowledge tomorrow"(11).

It is worth emphasizing multidisciplinary team integration, especially regarding the nutritionist, the awareness that food is the essential condition for patients' recovery; therefore, nurses should instruct their team to be present, observing and supervising the meals. The information given by the nutritionist should also be emphasized, bonding patients with this professional $^{(12)}$.

It makes it easier for the Nurse, if he/she has knowledge in Nutrition, to discuss the diet with the Nutritionist, to discuss the diet with the Physician, to understand why the Nutritionist is advising that diet (P2).

The integration of nutrition in other course subjects

In a question asked to the teachers about the existence of integration among the subjects, because it is a requirement in the Law of Educational Foundations and Guidelines, in the National Curricular Guidelines and the discussions held during the National Education Seminars, teachers have answered that the accomplishment occurs to a limited extent.

The subjects do not talk, fragment the curricula, and the challenges posed to the teacher precisely include "... linking the addressed content to other subjects..."(13).

The subject is isolated (P1).

We have not been able to do it up to today. It is hard, we try to link everything, telling the student: -You see, if you do not know it, it is not going to work later, when you study Women's Healthcare... (P5).

Provided with so many knowledge advances and possibilities of information dissemination, educative action in higher education institutions does not seem to move ahead at the same pace as changes and suitability to the needs of the current society. It is known that the way one sees and takes care of the human being must include a holistic approach. However, in practice, the institutions under analysis still cannot make communication among the subjects possible, to allow students to understand that they must see the human being as a whole, not only Nutrition and then Child Healthcare separately; because Child Healthcare comprises Nutrition as well.

Providing moments of integration among the subjects becomes essential to make the student understand the human being in a complete way, not in parts. 
For integration to occur, institutional leaders must be aware because, to make it possible for the teacher to get into a classroom with another teacher, and teach a class together through an approach, both teachers first need to understand the need and the benefits that exist for student learning in this kind of proposal. The teachers' pedagogical capability is also needed. Finally, the Institution must provide for planning moments, allowing the teachers to think over classroom practice, redirecting it whenever necessary.

Validating the assertions on the isolation of the subjects, it is emphasized that:

"As a curricular practice, there are many ways to make it possible; to join subjects whose contents allow for interdisciplinary pedagogical-didactic treatment (e.g. in specific projects related to social issues, major actual issues, unifying topics, etc."(14).

\section{FINAL CONSIDERATIONS}

The absence of integration among the subjects is clear in this study according to the teachers' reports. This makes it harder for the student to establish a relation among the contents of the subjects for their professional performance. The institution should formally provide opportunities for discussions among teachers. Fragmented teaching is no longer sufficient for current higher education needs; however, a path needs to be followed to achieve actual change.

The teachers' engagement in the Curricular Course Proposal is not feasible if they stay in the classroom fulltime. Teaching activity should not be limited to the classroom only. Their practice in the classroom needs to be reconsidered, to get to know it better and discuss about the Political-Pedagogical Project of the Course, to know in detail how their subject contributes to student education.

The importance of the existence of practice right in the first year of the course is pointed out for the students to get in touch with their future professional practice early in the course, and it is essential that they experience matters of higher and higher complexity levels and bring them to the classroom in their theoretical classes, discussions, also to enrich the theory and give meaning to the content.

It should be considered that the Nutrition subject does not need to be placed before practice, including because practice enriches theory. The important thing is to schedule the Nutrition subject after
Physiology and Biochemistry, but it is also necessary for the content of the Nutrition subject to be planned at exact moments in other subjects, promoting their integration, like in the subjects of Women, Child, Adult and Elderly Healthcare and in Psychiatry.

It is proved as a prevailing point of view among the interviewed teachers that the contents necessary for the Nutrition subject in the Undergraduate Nursing Course must comprise: General Concepts on Nutrition, Nutrition in the life cycle and Nutrition in view of diseases, including Enteral and Parenteral Nutrition. It should be emphasized that the teacher must plan the subject so as to observe the contents about the Nutritional Status of the Brazilian Population, a scenario the students will face in the future in their professional practice. It seems to be essential to include contents regarding people's cultural and religious aspects, as nurses must know how culture and religion influence the eating habits of the patients they deliver care to.

Besides the need for such contents, it is primordial to insert the Nutrition subject, even though it is a theoretical subject in the courses under analysis, in practical moments, with specific goals, when doing a research on the health condition of a certain population for instance, including aspects regarding the Nutrition of this population; in trainee programs in hospitals, verifying the integration of the multiprofessional team, how it works and the features of each professional regarding the patients' nutritional care; in trainee programs in Basic Health Units, when monitoring nursing consultations, paying attention to eating errors for future discussions in the classroom.

This research contributes to assert how important the Nutrition subject is in nursing education, considering health promotion and disease, both in the individual and the collective aspects.

It is believed that classrooms with a large number of students constitute a challenge for teachers nowadays, where certain dynamic activities become unfeasible. Nevertheless, teachers need to use their creativity to make the class less tiresome. Even if they choose an exposition class, it can take a dialogued form, in which the teacher encourages the student's participation, asking questions and requesting examples of students' experiences. The use of any teaching strategy is linked to its actual concern with the content; the teacher should feel prepared to use it, which demands planning, so that the strategy helps the teacher to carry out the class objective. 
This research indicated that the students' learning is still assessed in a classifying way, using written tests with multiple choice questions. In the extent of the Nutrition subject, besides verifying information retaining, the analysis of skills and attitudes of Undergraduate Nursing students needs to be observed in terms of Nutrition. Nutrition is a science that, by its characteristics, involves several health professionals and calls for an approach that also involves attitudes expected by the nurse in terms of nutritional care for the patients.

As several health professionals use Nutrition science, it demands a different approach for Nursing students, a particular way of teaching and learning. The teacher needs to check the importance and complexity of each content item. At the same time, the nurse must have Nutrition support in order to notice any eating error in clients and send them to a nutritionist. This peculiarity of Nutrition also demands a peculiar way of teaching. Nutrition teachers permanently need to point out the role of each professional in the health subject they are working on.

Nutrition teachers in Undergraduate Nursing Courses should exchange experiences and discuss strategies that best satisfy the students' teaching and learning processes. Although guidelines for discussions already exist, provided by the Regional Council of Nutritionists $3^{\text {rd }}$ region - CRN-3 regarding Nursing education, reflections are needed among Nutrition teachers in other health courses.

\section{REFERENCES}

1. Feresin C. Reflexões sobre a inserção da Disciplina de Nutrição na Formação do Enfermeiro: limites e possibilidades [dissertação]. São Paulo (SP): Universidade Federal de São Paulo/Escola Paulista de Medicina; 2005.

2. Boog MCF, Roncada,MJ, Stewien,GTM. Análise Crítica sobre os Objetivos das Disciplinas da Área de Nutrição e Dietética em Cursos de Enfermagem do Estado de São Paulo. Acta Paul Enferm 1996 maio-agosto; 9(2):32-8.

3. Ministério da Educação (BR). Lei no 9.394. Leis de Diretrizes e Bases da Educação. Brasília (DF): Ministério da Saúde; 1996. 4. Ministério da Educação e Cultura (BR). Conselho Nacional de Educação. Câmara de Educação Superior. Diretrizes Curriculares Nacionais do Curso de Graduação em Enfermagem. Resolução no 3, de 7 de novembro de 2001. Brasília (DF): Ministério da Educação e Cultura; 2001.

5. Ministério da Educação (BR). Exame Nacional de Desempenho dos Estudantes (ENADE) Enfermagem. Brasília (DF): Ministério da Educação; 2004.

6. Leopardi MT. Metodologia da Pesquisa na Saúde. Santa Maria (SP): Pallotti; 2001.

7. Bardin L. Análise de Conteúdo. Lisboa (Por): Edições 70; 1979. 8. Ministério da Saúde (BR). Secretaria de Atenção à Saúde. Departamento de Atenção Básica. Política Nacional de Saúde e Nutrição. Brasília (DF): Ministério da Saúde; 1999.

9. Batista NA, Silva SHS. O professor de medicina. São Paulo (SP): Loyola; 1998.

10. Pimenta SG, Anastasiou LGC. Docência no Ensino Superior. São Paulo (SP): Cortez; 2002.

11. Freire P. Pedagogia da Autonomia: Saberes necessários à prática educativa. São Paulo (SP): Paz e Terra; 1996.

12. Souza ALL, Jardim PCBV. A Enfermagem e o paciente hipertenso em uma abordagem multiprofissional - relato de experiência. Rev Latino-am Enfermagem 1994 janeirofevereiro; 2(1):5-17.
13. Sonzogno MC. Metodologias no Ensino Superior: algumas reflexões. In: Batista NA, Batista $\mathrm{SH}$, organizadores. Docência em Saúde: temas e experiências.São Paulo (SP): Senac; 2004. p.75-84

14. Libâneo JC. Adeus Professor, Adeus Professora?: Novas exigências educacionais e profissão docente. 7 ed. São Paulo (SP): Cortez; 2003. 